UDC: 656.121

\title{
Specifics of public transport routing in cities of different types
}

\author{
I. V. Makarova ${ }^{a}$, K. A. Shubenkovab ${ }^{b}$, V. G. Mavrin ${ }^{c}$, A. D. Boyko ${ }^{d}$ \\ Kazan Federal University, \\ 10a Syuyumbike prosp., Naberezhnye Chelny, 423812, Russia \\ E-mail: ${ }^{a}$ kamivm@mail.ru, ${ }^{b}$ ksenia.shubenkova@gmail.com, \\ cvadim_mmite@rambler.ru, ${ }^{\mathrm{d}}$ boykoaleksey94@gmail.com
}

Received 14.09.2020, after completion - 19.01.2021. Accepted for publication 21.01.2021.

This article presents a classification of cities, taking into account their spatial planning and possible transport solutions for cities of various types. It also discusses examples of various strategies for the development of urban public transport in Russia and the European Union with a comparison of their efficiency. The article gives examples of the impact of urban planning on mobility of citizens. To implement complex strategic decisions, it is necessary to use micro and macro models which allow a comparison of situations "as is" and "as to be" to predict consequences. In addition, the authors propose a methodology to improve public transport route network and road network, which includes determining population needs in working and educational correspondences, identifying bottlenecks in the road network, developing simulation models and developing recommendations based on the simulation results, as well as the calculation of efficiency, including the calculation of a positive social effect, economic efficiency, environmental friendliness and sustainability of the urban transport system. To prove the suggested methodology, the macro and micro models of the city under study were built taking into account the spatial planning and other specifics of the city. Thus, the case study of the city of Naberezhnye Chelny shows that the use of our methodology can help to improve the situation on the roads by optimizing the bus route network and the road infrastructure. The results showed that by implementing the proposed solutions one can decrease the amount of transport load on the bottlenecks, the number of overlapping bus routes and the traffic density.

Keywords: sustainable transport, transport system's efficiency, route network, public transport

Citation: Computer Research and Modeling, 2021, vol. 13, no. 2, pp. 381-394 (Russian).

The reported study was funded by RFBR, project number 19-29-06008 $\backslash 20$.

(C) 2021 Irina V. Makarova, Ksenia A. Shubenkova, Vadim G. Mavrin, Aleksey D. Boyko This work is licensed under the Creative Commons Attribution-NoDerivs 3.0 Unported License.

To view a copy of this license, visit http://creativecommons.org/licenses/by-nd/3.0/ or send a letter to Creative Commons, PO Box 1866, Mountain View, CA 94042, USA. 


\title{
Особенности маршрутизации общественного транспорта в городах разных видов
}

\author{
И. В. Макарова ${ }^{a}$ К. А. Шубенкова ${ }^{b}$ В. Г. Маврин, А. Д. Бойко \\ Казанский федеральный университет, \\ Россия, 423812, г. Набережные Челны, пр. Сююмбике, д. 10а \\ E-mail: ${ }^{\mathrm{a}}$ kamivm@mail.ru, ${ }^{\mathrm{b}}$ ksenia.shubenkova@gmail.com, \\ c vadim_mmite@rambler.ru, ${ }^{\mathrm{d}}$ boykoaleksey94@gmail.com
}

Получено 14.09.2020, после доработки - 19.01.2021. Принято к публикаџии 21.01.2021.

\begin{abstract}
В статье представлена классификация городов с учетом планировочных особенностей и возможных транспортных решений для городов различных типов. Также обсуждаются примеры различных стратегий развития городского общественного транспорта в России и странах Европейского союза с сопоставлением их эффективности. В статье приводятся примеры влияния городского планирования на мобильность граждан. Для реализации сложных стратегических решений необходимо использовать микрои макромодели, которые позволяют сравнивать ситуации «как есть» и «как будет» для прогнозирования последствий. Кроме того, авторы предлагают методику совершенствования маршрутной сети общественного транспорта и улично-дорожной сети, которая включает определение потребностей населения в трудовых и учебных корреспонденциях, идентификацию узких мест улично-дорожной сети, разработку имитационных моделей и выработку рекомендаций по результатам эксперимента на моделях, а также расчет эффективности, включающий расчет положительного социального эффекта, экономическую эффективность, повышение экологичности и устойчивости городской транспортной системы. Для обоснования предложенной методологии были построены макро- и микромодели исследуемого города с учетом пространственной планировки и других особенностей города. Таким образом, на примере города Набережные Челны показано, что использование нашей методологии может помочь улучшить ситуацию на дорогах за счет оптимизации сети автобусных маршрутов и дорожной инфраструктуры. Результаты показали, что при реализации предложенных решений можно уменьшить транспортную нагрузку на узкие места, количество перекрывающихся автобусных маршрутов, а также плотность движения.
\end{abstract}

Ключевые слова: устойчивый транспорт, эффективность транспортной системы, маршрутная сеть, общественный транспорт

Исследование выполнено при финансовой поддержке РФФИ в рамках научного проекта № 19-29-06008 20. 


\section{Introduction}

The world economy in the new millennium is characterized by two main trends. On the one hand, it is the rapid development of engineering and technology that requires significant amounts of resources and that causes the emergence of an increasing number of sources of negative impact on the environment. On the other hand, it is the growing number of supporters of transition to a green economy that initiate the development of strategies and policy documents on sustainable development in all spheres of human activity. The processes of globalization and urbanization are accompanied by the growth of transportation demand and, consequently, require an increase in the stability and safety of transport systems. Negative consequences of urbanization, development of the real sector of the economy and unwarranted harmful environmental impact of the humanity is the reason of the priority of the 5 sectors underpinning the UNEP (United Nations Environment Programme) report "Global Green New Deal". One of these sectors is the "Sustainable Cities, including Planning, Transportation and Green Building" [United Nations Environment Programme, Electronic resource]. The three-pronged strategy of UNEP in the area of transport, a sector, which accounts for approximately one quarter of all energy-related greenhouse gas emissions, is "Avoid - Shift - Clean". This UNEP's program is promoting a paradigm shift for a less motorized, but no less mobile, world. A lot of methods are proposed to solve this problem. One of the most promising methods is intellectualization of the transportation process. Mobility is key dynamics of urbanization. By 2005, approximately 7.5 billion trips had been made in cities worldwide each day. In 2050, there may be 3 to 4 as many passenger- and freightkilometers travelled as in the year 2000. Transition to inclusive green economy should be based on viable ecosystems, cleaner production, and healthy consumer preferences.

\section{New trends in urban mobility}

\subsection{Impact of sustainable urban development on the transport system}

Examples of sustainable cities, as a rule, belong to the most developed countries (biopositive countries). Currently, examples of countries that have embarked on a path of sustainability are Germany and the Netherlands. For example, Germany, which had by the beginning of the 20th century only about $4 \%$ of the areas under forests, currently has about $25 \%$ of the forested areas [Geography of Germany, Electronic resource]. Germany is a country of small cities surrounded by a large number of forests, fields, and farms. Thus, the length of Frankfurt am Main from east to west is $10 \mathrm{~km}$, from north to south $6 \mathrm{~km}$, and the area of the city is only about $60 \mathrm{~km}^{2}$. Nevertheless, Frankfurt am Main is the largest logistics and transport hub in Europe, the city has the largest airport in Germany, and is also positioned as a European financial center. These "incompatible" characteristics were achieved due to the principles of sustainability, a competent urban lands use, a policy in the field of public transport, which, for example, resulted in the total reconstruction of the city's tramway system by its expansion and modernization. Today, the problem of sustainability is relevant in the Russian context. In the last 20 years, the humanization of the urban environment has grown in Russia by improving the aesthetic and functional characteristics of buildings and structures, but there is a discrepancy between architecture and man in big Russian cities. This is because the existing master plans cannot always be realized in practice because of the rapid change in the political and momentary utilitarian and practical conjuncture. It is stated in [Tetior, 2007] that the sustainable city environment may be improved with the help of eco-friendliness: 1. Integration of social, economic and ecological factors into the creation of the sustainable city environment. 2. Maintenance of a high-quality eco-friendly infrastructure in sustainable city and nearby to support the quality of environment. 3. Eco-friendliness of the architectural-building environment to provide satisfaction of citizens' needs and, at the same time, to achieve an ecological equilibrium. 4. Eco-friendliness of all activities in city-industry, power engineering, transport, water consumption, waste processing, etc. 5. Eco-friendliness of citizens' needs and inculcation of ecological ethics. 
Eco-city encourages public transport that either does not pollute environment at all or has only small pollution. The advantage is given to electric transport (an ideal is electric transport in an underground tunnel, e.g., metro), personal electric cars or gas-driven vehicles. Pedestrian traffic and cycling are encouraged: for this purpose, a special network of pedestrian and bicycle paths that do not intersect with transport routes, parking lots and parking for bicycles is built. All private parking facilities are located on the borders of the eco-quarters, so that there is no passage inside the quarters, and it is recommended to equip highly loaded sections by moving sidewalks [Sustainable urban development, Electronic resource].

One of the interesting solutions in the biopositive country is the creation of "green" corridors that connect all the green areas and natural landscapes with each other. These corridors should be created in the scale of the country, city, microdistrict. The main idea of the "green" corridors is to ensure the possibility of migration of animals so that their paths do not intersect with roads and buildings, and to ensure the possibility of walking on sidewalks. For free migration, these corridors should nowhere intersect at the same level with the transport highways. Interchanges in the form of overpasses, pipes, and tunnels under roads should be built in order that the corridors can be crossed.

Much attention should be paid to supporting bicycle transport [Makarova et al., 2019]. For bicycle routes, individual paths are built along the usual motorways, or individual bicycle paths are made on the level of the 2 floors (on supports) or on the level of the day surface. There are Bicimetro - Eco Bahn projects for different cities. To improve the quality of life in cities, it is necessary to place bicycle paths on the most convenient territory. This will provide residents with the possibility of a safe movement for man and nature. If one transfers vehicles to the ground, one can clean the polluted air from transport tunnels by filtration.

\subsection{Smart transport as one of the drivers of smart city development}

There is a need for substantial changes in Europe's transport systems, as well as in the mobility behavior of people and businesses in urban areas. Solutions concern the creation of an efficient and integrated mobility system that allows organizing and monitoring seamless transport across different modes, increasing the use of environmentally-friendly alternative fuels, and creating new opportunities for collective mobility. The proposed solutions lead to a decreased environmental impact. Ensuring the mobility of population means ensuring access to all functions, services, places of work, etc. At the same time, city residents should be able to address their needs using as little travel as possible. It can be completed in two ways: (1) reducing the needs to travel by implementing modern information and communications technologies (Internet of Things, Industry 4.0 and other concepts) and (2) reducing distances between places of residence and functional endpoints (the reasons for travel), so that the population could use more sustainable modes of transport, such as walking, cycling, etc.

To make people use more sustainable mobility concepts, it is necessary to ensure the possibility of reaching any point of passengers' attraction by public transport. However, sometimes it is rather difficult to allow residents' easy access to the public transport system: it is the so-called Last Mile Problem [Liu et al., 2012; Makarova et al., 2017c; Bordagaray et al., 2012; Galkin et al., 2019]. To solve this problem, cities need to provide multi-modal transport systems. For example, bicycle sharing systems can serve as a good way to connect users to public transit networks. Transport system is one of the major intellectual systems in the Smart City. To ensure its sustainability and safety, the work is being done in three ways: smart infrastructure, smart vehicles and smart users. Solutions concern the creation of an efficient and integrated mobility system that allows for organizing and monitoring seamless transport across different modes, increasing the use of environmentally friendly alternative fuels and creating new opportunities for collective mobility. One of the main areas of ITS, which has been actively promoted over the past 15 years, is the implementation of intelligent vehicles. The international program "Increased safety vehicle" is implemented. The first experiments of usage of onboard intelligent systems have shown that they are able to reduce the number of traffic accidents by $40 \%$ and to reduce the number of fatal accidents by $50 \%$. The transition from the creation of driver assistance systems to the development of semi-autonomous unmanned vehicles is a global trend, and it 
is explained by the desire of developers to ensure the sustainability and the transport system safety [Lin et al., 2013].

However, it should be understood that the emergence of new types of vehicles with fundamentally new control systems could cause problems of security and interaction with other road users. It is especially true in connection with the development of the "livable cities" concept that is aimed at encouraging the non-motorized mobility, such as walking or cycling On the one hand, streets need to be adapted, with safe walkways, crossings and cycling lanes, as well as transport junctions need to be established to create safe connection points between different transport modes. On the other hand, it is necessary to identify potential risks of the use of autonomous vehicles, to predict the likelihood of the traffic conflicts (between autonomous vehicles and pedestrians and cyclists, first of all) and to determine the possible consequences. In addition, ways should be devised to prevent risk situations and to reduce the severity of the consequences should such situations arise.

Road transport is the main transport in urban areas, so if vehicles traffic management is inefficiently, then it can create significant problems for other road users. In addition, the quality traffic management reduces the negative impact of vehicles on the environment. The main idea of Smart City is that the city can be "smart" only if the management of all its subsystems is built according to the same rules. If we talk about road transport, then it actually means the management of the vehicle's life cycle as a separate component of the vehicle fleet, and at a higher level, the management of the vehicle fleet as a whole. Along with it, all processes at all stages of the life cycle should be intellectuallized. At the same time, the orientation to customer needs should be one of the main factors that should be taken into account when planning and implementing these processes. That is why, when solving this class of problems, it is more rational to use different methods that don't require full information, for example, heuristic methods [Stańczyk et al., 2018; Alsolami et al., 2019], Bayesian approach [Zhou et al., 2017], dynamic programming approach [Zielosko, Żabiński, 2018] and process modelling methods [Lur'e, 2010; Jiménez, Román, 2016; Kazhaev et al., 2018].

\subsection{Cities' spatial planning and their influence on citizens' mobility}

Sustainable cities cannot exist without sustainable mobility. Apart from the shift to renewable energy sources, we should not forget about the shift towards more sustainable transport modes like public transport. It plays an indispensable role to make the cities livable and less polluted. Sustainable urban mobility plans and transport strategies are therefore aimed at reducing mobility demand, shifting to environmentally friendly modes of transport such as walking, cycling and car sharing, increasing the share of public transport and clean vehicles, and the use of state of the art technology for the remaining individual motorized transport. Reducing travel distances and travel demand is therefore an important cornerstone for sustainable urban transport. This implies that the city's inhabitants should not be forced to travel far to cover their basic needs. Distances should ideally be kept so short that walking or cycling is the attractive/likely mode of transport.

Short distances also improve the possibilities for an enhanced modal shift. This is important to achieve a fair transport system that gives all groups in society equal or high accessibility to important services, independent of car ownership. Transport demand reduction is achieved through the application of sustainable spatial planning policies that support and encourage cross-functional development. This planning ensures the location of housing, shops and jobs within walking and cycling distance or close to convenient public transport. For urban planning assessment of the transport system, the indicators specified in the regulatory documents are used.

The regional patterns of settlement that have developed in Russia, as a rule, do not correspond to the idealized ecological scheme. Thus, the studies by the Central research and design Institute of Ministry of construction of Russia in Central, Volga-Vyatka and North-West regions of Russia made it possible to establish that the zoning and structure of the large agglomerations, such as the Moscow, Nizhny Novgorod, Tula and many other territories, do not rise to the tasks of ecologically balanced development of natural and urbanized landscapes. 
Currently, the sustainable development of the largest cities (megacities) of the Volga region, Kazan and Ufa, has just begun. For example, over the last two years, the city authorities of Ufa have adopted a program to expand streets by eliminating lawns and cutting down part of the trees. This city is the third in Russia in length, but in the narrowest place its areas are connected only by means of three streets, which causes traffic jams. The city's master plan for the city's development suggests further expansion around, without taking into account the construction reserves on the Ufa Peninsula. In the city, which has more than two hundred public transport routes and more than 1800 transport units, a significant part of which passes through one avenue, no one has implemented any specific proposals for optimizing the network, although over the past year, the city authorities have presented many promising projects in this direction.

Kazan also has a lot of problems that hinder sustainable development. First, they include a large residential blocks of the same type - serial apartment houses built in the 1970s with underdeveloped yard spaces and adjacent social sphere. This creates a low-quality environment in areas within residential areas due to physical, moral and aesthetic wear and tear. The municipal programmes provide only minimal care for the existing landscaping and playgrounds. The significant degeneration of the tram network and the stagnation of the trolleybus network do not correspond to the development of a sustainable eco-friendly transport frame of the city. To improve the environmental transport of Kazan "Architectural Studio Arthur Atbegin" created a cycleways project, which was published on the website "Architecture of Russia". Cycleways (Bicimetro) is raised above the street level bike lanes in tunnels. The project of covered Bicimetro is relevant, first of all, for Russia because of climatic conditions. Bicimetro makes it possible to ride bikes and velomobiles all the year round, in any weather. Bicimetro in combination with conventional bike lanes create a full bikes' transportation network. It ensures the safety of travel, independence from traffic jams and other transport problems, while unloading the urban transport system.

In 2010, a strategy was proposed to register the cities that are being created [Richardson et al., 2016]. On this basis, the urban project was patented - the concept of the city "Solntsegrad", which reflected the practical aspects of sustainable development of the city, including its appearance. "Solntsegrad" is designed as a kind of template city, which can be implemented in different regions. At the same time, adaptation taking into account features of the geographic area is provided. This project or parts of it can be used as a basis for the development of the adapted city in almost any region of Russia or in Europe. Its main idea is to attempt to combine modern development trends and the accumulated Russian and Soviet urban development potential. During the development of the project, a city comparable to the regional centers was formed.

The city as a whole and its center have a classical planning structure, it is very similar to European and old Russian cities. The experience of creating the Moscow layouting scheme was borrowed in the creation of ring roads, but in the project they are turned into semi-rings, closing the city from the west. The project of the city provides for radial-ring structure and chords. This concept is the development of the idea of architects J. Stubben and O. Wagner, who believed that the radial-ring system is optimal. The basic principles of the plan "Solntsegrad" can be combined in the "Concept of Four". These are the four main directions of highways and the four main lines of development, polycentric structure of the city environment, four green zones and four main industrial clusters in the urban fabric of the city. All the principles are closely interrelated and aimed at creating a city that is comfortable for modern living.

The main part of the city's transport system is urban passenger transport. The main indicator of passenger transport is the time spent on traveling, including pedestrian approaches. Today, for large and major cities, the norm is 40 minutes for $80-90 \%$ of passengers; in other cities, 30 minutes. The city's transport network must meet the following requirements:

- Provide comfortable passenger communications along the shortest routes;

- Provide comfortable passenger connections for the external transport hub facilities with residential areas and the city center

- transport lines must run in the direction of the main passenger traffic; 
- the length of transport lines should be in accordance with the total area of the city and the number of vehicles traveling on the network;

- the length of the transport network should be minimal provided that the maximum service of the city territory is ensured;

- ensure that the expected number of vehicles can pass;

- Provide the necessary delivery speeds, meeting the standard requirements;

- The transport network should ensure the reliability of the transport system, in the event of traffic blocking, in some parts of the network, there should be bypass directions;

- The system of urban mass passenger transport should ensure the functional integrity and interconnectedness of all the main structural elements of the urban area, taking into account the prospects for the development of the city and the region;

- When developing the project of organization of public transport services, the population should ensure the speed, comfort and safety of the transport movements of the city's permanent and temporary population, as well as of daily migrants in settlement systems.

- Lines of ground public passenger transport should be provided on the main streets and roads with the organization of the movement of vehicles in the general flow, along a designated strip of the carriageway or on a separate lane.

\section{Optimization of urban transport system: case study of the city of Naberezhnye Chelny}

\subsection{Optimization of the bus route network}

Naberezhnye Chelny, one of the youngest Russian cities, is a major railway, motor transport, and aviation hub, known on the Kama river port. An open type of linear structure with the "classic" functional zoning was used as a basis for planning organization of the city with a parallel location of industrial and residential areas and suburban recreation zones. Longitudinal highways which connect the residential areas of the city compose a transport-planning frame of the city that gives rise to attribute the planning scheme of its road network to rectangular. The main "diameter" of the city is a longitudinal thoroughfare, which includes M. Jalil avenue, Naberezhnochelninsky avenue, and Mira avenue [Sładkowski, Pamuła, 2015]. One more feature of the cities of similar planning is the proportional distribution of the population throughout the residential area, and there are kindergartens, schools and shops in each residential district (complex). It was made in order to minimize the number of trips to education and shops. Due to the fact that a significant part of all trips during peak hours are the trips to (from) work, the separation of industrial and residential areas causes problems on the longitudinal and cross streets' intersections.

Public transport represents 14 tram routes, more than 25 bus routes and taxi, the taxi (including the so-called social taxi carrying several passengers fares in taxis). Naberezhnochelninsky tram is one of the latest new tram systems in the USSR and Russia, which is close to the light rail. One of the very few in post-Soviet Russia, a tram system of the city has increased in the 1990s and 2000s, and has plans for further development, including both new lines in the city, and creating an inter-city light rail line to the city of Yelabuga. Expansion of the tram route network and its combination with the existing bus route network can help to reduce the traffic load of road network. In 2009, the city launched a reform of the city bus system. Its aim was to displace small capacity buses and to update the bus fleet and the route network. In 2013 city carriers have bought 100 new gas-driven buses of large capacity: 84 buses for urban transportation and 16 for suburban transportation. In 2015 optimization of urban bus transport was made: 136 new gas-driven buses of large capacity NEFAZ-5299 were bought. All shuttle buses are equipped with GLONASS devices.

The Strategy of social and economic development of Naberezhnye Chelny till 2030 [Strategy of social and economic development of the city of Naberezhnye Chelny until 2021 and for the period up to 2030, 2016] is aimed at increasing the city transportation system's sustainability. But, from our 
point of view, the existing strategy pays insufficient attention to non-motorized modes of transport as well as to multimodal transportation development. For example, construction of the walking and cycling facilities is planned only along the river walk, i.e., as a recreational area, not as an element of the city transport infrastructure. At the same time, in the case when the destination point is situated on the longitudinal avenue that is parallel to the point of departure (in connection with the peculiarities of urban planning described above) and there is a lack of lateral routes of public transport in the city, the "last mile" problem exists.

To assess the functioning of transport systems in the case of changing certain parameters, it is customary to use methods of simulation [Stukalov, 2013]. Analysis of the possibilities and designation of existing software developments for modeling traffic movement showed that the best option for solving the problem of forecasting traffic loads in urban areas is a specialized modeling package at the macro level - PTV VISUM.

One of the main factors having an effect on the characteristics of transport systems is the transport demand of the population, which is the basis of correspondence matrices. The study consisted of several stages. In the first phase, a survey was organized involving more than 300 respondents. The results of the survey made it possible to create a correspondence matrix. After that, the macroscopic transport model of the city was created. Validation and verification of the model was carried out based on the results of field observations of traffic flows.

The problem of overloaded roads is a topic of pressing concern for Naberezhnye Chelny, despite the fact that it was designed with the possible growth of the number of both personal and passenger vehicles on the roads. In view of the fact that a significant part of trips during peak hours are labor trips, the separation of industrial and residential areas in the city creates problems at the intersections of longitudinal and transverse highways. This is due to the fact that for the delivery of workers to industrial zones there was a network of factory routes. Currently, there are no such routes, but the route network of urban public transport has not changed significantly. Therefore, employees are forced to travel to work by personal vehicles. Besides, a hypothesis was put forward of the possibility of reducing the transport load on the city's roads by the transition from the traditional form of education to the mixed education. Figure 1 shows a map of the city with locations of educational institutions of higher and secondary special education. The process of building a transport model of Naberezhnye Chelny is described in our previous article [Makarova et al., 2016]. We chose to study one of the most problematic sites of the city's road network, which merges routes connecting the old and new parts of the city. It is central avenue - Naberezhnochelninsky where there are 5 educational institutions.

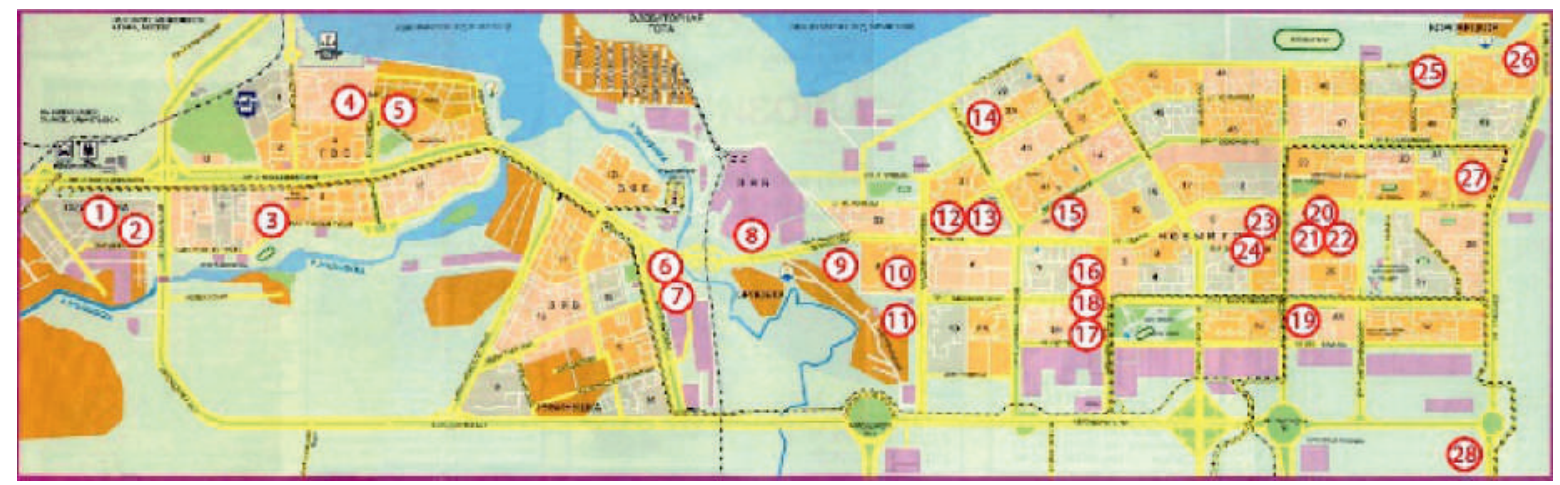

Fig. 1. Location of educational institutions of the city of Naberezhnye Chelny. Educational institutions are marked by numbers

In developing a new route network of bus transport, it is necessary to take into account the following aspects:

- All transport districts in the city must be connected to each other by direct routes. Special attention must be given to new districts with underdeveloped transport infrastructure.

- Improvement of the route network should reduce situations where routes overlap each other. 
- The time interval between arriving buses must correspond to standard values and satisfy fully the transport demand of population.

- Choice of vehicles for each route and bus timetable must be made according to predicted values of transport mobility and must be corrected according to changes in traffic parameters.

Although the existing configuration of road and street network do not allow one to avoid completely the overlapping of public transport routes, it is possible to reduce significantly the number of routes which run along the same segment of road network, thus having saved an opportunity to satisfy mobility of urban population. Figure 2a presents a part of the existing route network together and shows the numbering of routes which run along a problematic segment of the road network. The upgraded bus route network is shown in Fig. $2 \mathrm{~b}$.
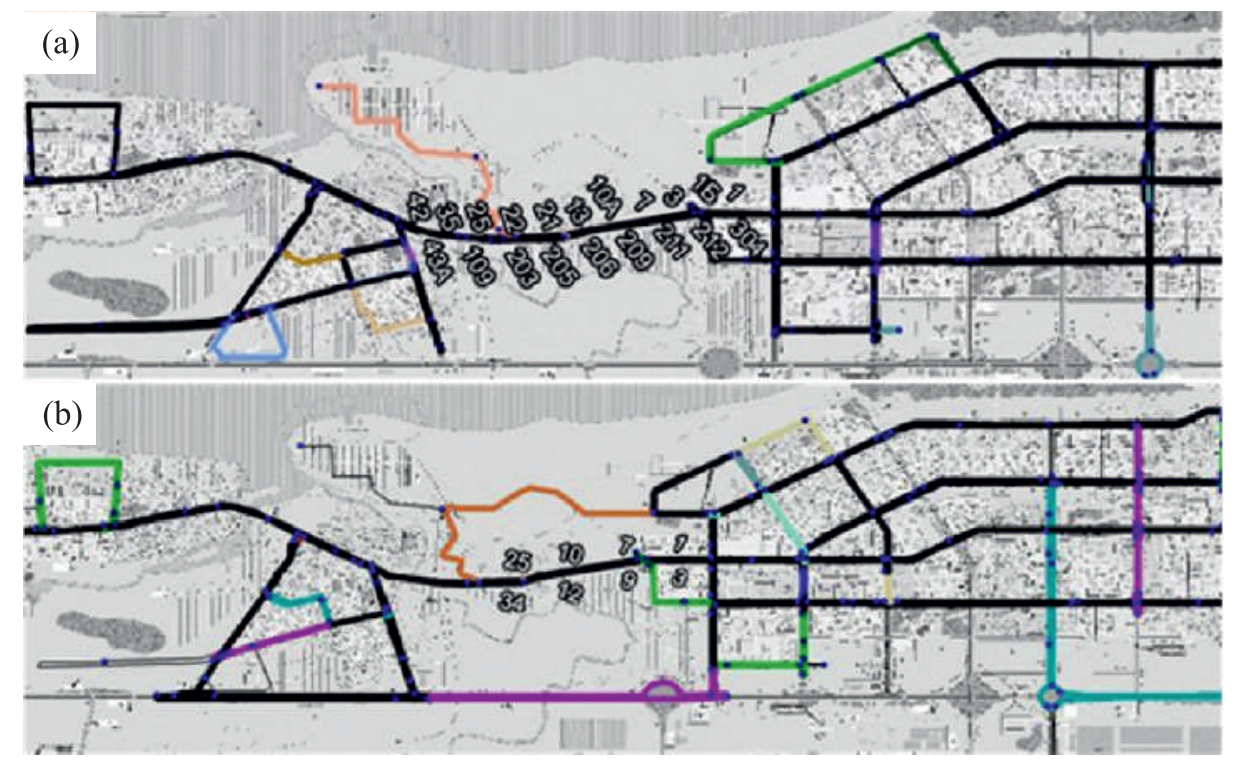

Fig. 2. Scheme of the existing route network with the numbering of routes that run along a problematic segment of the road network (a); the upgraded bus route network (b)

Table 1 . Traffic intensity of vehicles

\begin{tabular}{|l|c|c|c|c|}
\hline \multirow{2}{*}{$\begin{array}{c}\text { Name of the road } \\
\text { section }\end{array}$} & \multicolumn{2}{|c|}{$\begin{array}{c}\text { Intensity of vehicles } \\
\text { in GES direction per day }\end{array}$} & \multicolumn{2}{c|}{$\begin{array}{c}\text { Intensity of vehicles } \\
\text { in NG direction per day }\end{array}$} \\
\cline { 2 - 5 } & existing & predicted & existing & predicted \\
\hline Centralnaya & 33700 & 32260 & 33180 & 25716 \\
\hline Bumazhnikov & 39024 & 37800 & 32176 & 30280 \\
\hline Pedinstitut & 51236 & 39992 & 50196 & 42512 \\
\hline Chelnygorstroy & 51316 & 39104 & 50196 & 42512 \\
\hline Medgorodok & 40261 & 35032 & 32544 & 28608 \\
\hline 7 kompleks & 12064 & 11672 & 18304 & 13248 \\
\hline Rayispolkom & 12064 & 11056 & 18304 & 15008 \\
\hline Avtozavodskiy & 15776 & 11328 & 12453 & 10592 \\
\hline
\end{tabular}

A fragment of the transport model visualization built in PTV VISUM is presented in Fig. 3, and Table 1 shows a comparison of transport load values on the most problematic segments of the road network according to existing and proposed route networks. The presented road sections were identified as problematic based on congestion and road accidents statistics [Traffic police, Electronic resource]. It is predicted that the number of vehicles on these road sections will be decreased: first of all, the number of buses duplicating each other will decrease, and secondly, a survey conducted by us [Makarova, et al., $2017 \mathrm{~b}$ ] has revealed that after improving the route network and adapting it to the needs of the population, people will more often choose passenger vehicles as a means of transportation rather than personal cars. 


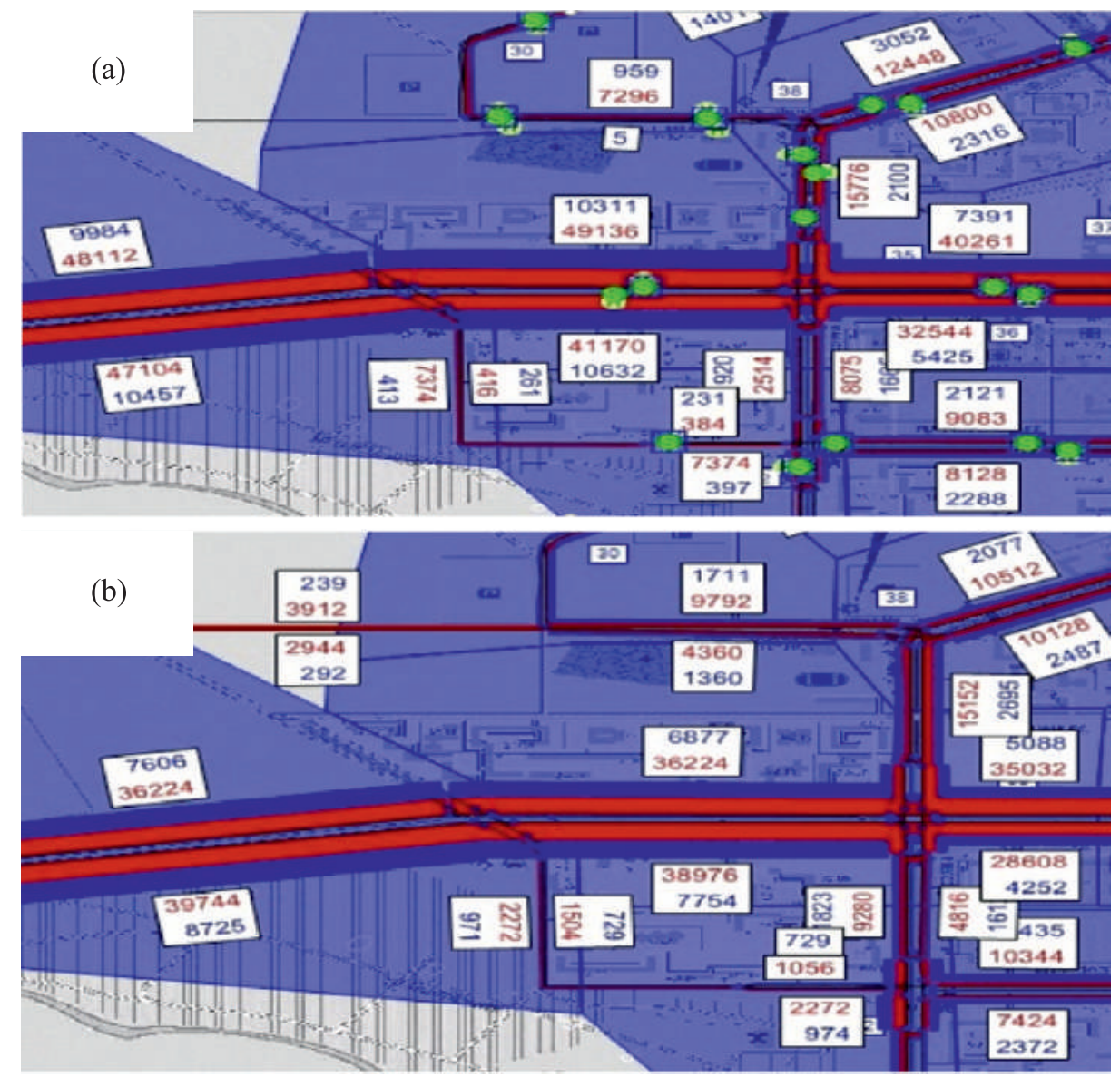

Fig. 3. Distribution of transport load according to: a) the existing passenger flow and the route network; b) the predicted passenger flow and the upgraded route network. Red numbers indicate the number of private vehicles passing through this segment, blue numbers indicate the number of public transport passengers

\subsection{Optimization of road infrastructure}

The quality of the transport system's operation and its safety are often affected by the configuration of the road network and the quality of management. To analyze, we have chosen one of the bottlenecks of Naberezhnye Chelny (intersection of Avenues Druzhba Narodov, Syuyumbike and Mira). At peak hours, this road section does not cope with the traffic flow: there are overloads, serious traffic jams and in accordance with the traffic police statistics, high statistics of road accidents [Ministry of the Interior of the Russian Federation, Electronic resource]. Drivers spend a lot of time maneuvering around corners because of the huge flow of vehicles. These dangerous problems arise due to the nonoptimal organization of traffic flows. The situation was aggravated by the introduction of a new line in tram routes network.

The optimal method for analyzing the situation in local areas of the city are micromodels [Makarova et al., 2017a]. We created a simulation model in AnyLogic 7 on the basis of a discreteevent approach using the library of traffic. The results of experiments on the model showed that the geometry of the studied road segment adversely affects the characteristics of the traffic, since it does not correspond to the parameters of the flow of motion. To improve the situation, we suggested organizing a circular movement which reduces the number of conflict points on this stretch of the road. The experiment was carried out by comparing two variants of the model with similar input parameters of the transport flows (Fig. 4). 

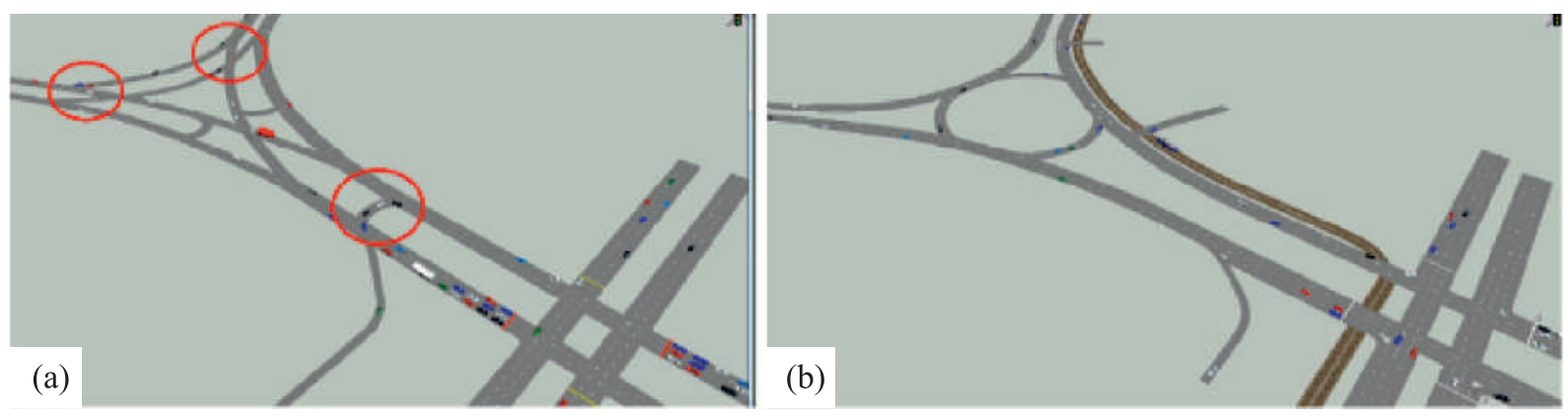

Fig. 4. Simulation model a) before optimization; b) after optimization

Besides, we have suggested applying at the adjacent intersection (Avenues Druzhba Narodov and Mira) traffic light regulation with alternative number of phases, i.e., a set of main and intermediate traffic light stages. We have conducted a simulation experiment for selecting the optimal duration of the traffic light-signal phase. To verify the model built, we made field observations of traffic intensity on this road section during different parts of the day and on different days of the week. The correlation coefficient of observational data and values obtained from the model was determined using special software STATISTICA. Since the Pearson correlation coefficient is 0.98 (at the $5 \%$ significance level), the constructed simulation model can be used to improve the traffic organization on this road section. Analysis of the results of the study of this road section showed that the most acceptable option is to organize on this road section circular traffic and changes in traffic light control. The results of the optimization experiment conducted in AnyLogic demonstrate that the traffic parameters of the road section under study could be greatly improved (traffic density can be decreased by $34 \%$ : from $95 \%$ to $61 \%$ (see Table 2, which shows changes in the traffic light phase with adaptive control, depending on traffic density)).

Table 2. Traffic light phase change on the crossroad depending on the traffic density

\begin{tabular}{|c|c|c|c|c|c|}
\hline \multirow{2}{*}{$\begin{array}{c}\text { Traffic density } \\
\text { of the road section }\end{array}$} & \multirow{2}{*}{$\begin{array}{c}\text { Total stage } \\
\text { duration, sec. }\end{array}$} & \multicolumn{2}{|c|}{ Basic tact, sec. } & Red and yellow & Yellow signal, \\
signal, sec. & Red signal & Green signal & \\
\hline $\mathbf{9 5 \%}$ & 85 & 41 & 38 & 3 & 3 \\
\hline $\mathbf{8 2 \%}$ & 83 & 37 & 40 & 3 & 3 \\
\hline $\mathbf{7 4 \%}$ & 82 & 35 & 41 & 3 & 3 \\
\hline $\mathbf{6 1 \%}$ & 81 & 32 & 43 & 3 & 3 \\
\hline
\end{tabular}

Moreover, we have developed a fuzzy algorithm for regulating traffic lights on the pedestrian crossings. It is described in our other paper [Makarova et al., 2018].

\subsection{Efficiency assessment of our proposed solution}

The efficiency of the proposed solution consists of 4 components: positive social effect (SE), economic efficiency (EE), increasing environmental friendliness and sustainability of the urban transport system. For example, the EE could be considered as savings on costs per one transported passenger associated with fuel products. Such an effect could be reached by reducing the number of vehicles and the total number of kilometers on routes and by operating gas-driven buses. To calculate the EE, the following formula is used:

$$
E E=\sum_{k=0}^{2} \frac{L_{k} \cdot F C_{k} \cdot P_{k}}{100 \cdot N_{k} \cdot q_{k}},
$$

where: $k$ is the type of buses which operate on the route: $k=1$ if buses have a small capacity (18 persons) and run on Diesel fuel; $k=2$ if buses have a large capacity (115 persons) and run on Diesel or 
gas engine fuels; $L_{k}$ is the total number of kilometers covered by all buses of type $k, \mathrm{~km} ; F C_{k}$ is the fuel consumption of buses of type $k, 1 / 100 \mathrm{~km} ; P_{k}$ is the price of the fuel used by buses of type $k$, rubles; $N_{k}$ is the number of buses of type $k ; q_{k}$ is the passenger capacity of a bus of type $k$, persons.

The positive SE could be assessed by using the number of transported passengers and by using different types of time delays and, especially, their reduction. Time delays concern not only the time spent by passenger waiting for a bus and idle time spent by the bus at bus stops, but also the idle time spent in traffic jams. To combine particular values of passenger travel time between two transport districts into a single criterion of SE, it is necessary to adjust them to a common basis (per one transported passenger):

$$
S E=\frac{\sum t_{l-m}}{\sum_{k=1}^{2} N_{k} \cdot q_{k}},
$$

where: $l$ is the index number of the district of departure, $m$ is the index number of the district of destination, and $t_{l-m}$ is the passengers' travel time from district $l$ to district $m$, min.

Environmental performance is provided in 2 ways. The first tool is reducing the total number of buses traveling along problematic sections of the road network. The second approach is based on the idea of replacing Diesel-powered buses by more ecological ones, which are powered by methane. The volume of pollutants (VP) is calculated according to (3):

$$
V P=\sum_{k=0}^{2} \frac{N_{k} \cdot H_{k}}{1000},
$$

where: $H_{k}$ is the content of pollutants in the engine exhaust gases, gr.

The positive influence of the proposed solution on the transport system sustainability could be assessed with regard to the approximation of its parameters to target values of the system, which are recommended in various regulatory documents. For this purpose, an integrated efficiency indicator was developed and a "radar map" was built. The key efficiency parameters were pointed out and calculated for the existing and proposed route networks. We have described in detail our assessment methodology in our previous article [Shubenkova, Makarova, 2018].

\section{Conclusion}

A transportation system is the basis of any city: it contributes to economic system development through transportation of passengers to their places of work and cargos' delivery to all enterprises of the city. At the same time, the transport system is the main source of environmental pollution. Thus, the advantages of increased mobility need to be weighed against the environmental, social and economic costs that transportation systems pose. The possibility of increasing the sustainability of the transport system was considered in the case study of the city of Naberezhnye Chelny. The following tools were chosen: optimization of the bus route network, improvement of the road infrastructure, as well as optimization of vehicle fleet on routes in accordance with the real transport demand of population. It was shown that a decrease in route overlapping, local public opinion poll in designing new routes, usage of buses with large capacity as well as use of more environmental friendly types of buses allow an increase in the quality of transport service and the population mobility together with a decrease in negative environmental impact and load on the urban road network. Also, complex parameters for assessing the efficiency of the proposed solution and the sustainability of the transport system were described. The measures listed in this article can be used independently of each other and can yield certain insignificant results. However, their integrated implementation will provide the maximum effect and significantly reduce the negative impact of road transport on the environment. 
This approach contributes to the development of the theory of improving the transport infrastructure of urbanized areas and opens up prospects for increasing urban mobility while reducing the negative impact of the transportation process on the environment.

\section{References}

Alsolami F., Amin T., Moshkov M., Zielosko B., Żabiński K. Comparison of heuristics for optimization of association rules // Fundamenta Informaticae. — 2019. - Vol. 166, No. 1. - P. 1-14.

Bordagaray M., Ibeas A., dell'Olio L. Modeling User Perception of Public Bicycle Services // Procedia - Social and Behavioral Sciences. - 2012. — Proceedings of EWGT2012. - Vol. 54. P. 1308-1316.

Galkin A., Obolentseva L., Balandina I., Kush E., Karpenko V., Bajdor P. Last-mile delivery for consumer driven logistics // Transportation Research Procedia. - 2019. — Vol. 39. - P. 74-83.

Geography of Germany [Electronic resource]. — URL: https://en.wikipedia.org/wiki/Geography_of_ Germany (accessed: 03.09.2020).

Jiménez F., Román A. Urban bus fleet-to-route assignment for pollutant emissions minimization // Transportation Research Part E: Logistics and Transportation Review. - 2016. - Vol. 85. P. 120-131.

Kazhaev A., Almetova Z., Shepelev V., Shubenkova K. Modelling urban route transport network parameters with traffic, demand and infrastructural limitations being considered // IOP Conference Series: Earth and Environmental Science. — 2018. — Vol. 177, No. 1. — 012018.

Lin J.-R., Yang T.-H., Chang Y.-C. A hub location inventory model for bicycle sharing system design: Formulation and solution // Computers \& Industrial Engineering. — 2013. - Vol. 65, Iss. 1. P. 77-86.

Liu Z., Jia X., Cheng W. Solving the Last Mile Problem: Ensure the Success of Public Bicycle System in Beijing // 2012 - Proc. ICTTS. - 2012. - Vol. 43. - P. 73-78.

Lur'e M. V. Mathematical simulation of street traffic in the presence of traffic lights // Mathematical Models and Computer Simulations. - 2010. - Vol. 2, No. 3. - P. 388-395.

Makarova I., Boyko A., Tsybunov E., Zabiński K., Abeshev K. The use of the decision support system to control bicycle transportation // Proceedings of the 5th International Conference on Vehicle Technology and Intelligent Transport System (VEHITS 2019). — Creta, 2019. - P. 649-656.

Makarova I., Khabibullin R., Pashkevich A., Shubenkova K. Modeling as a Method to Improve Road Safety during Mass Events // Transportation Research Procedia. - 2017a. - Vol. 20. P. 430-435.

Makarova I., Khabibullin R., Shubenkova K., Boyko A. Ensuring sustainability of the city transportation system: problems and solutions (ICSC) // International Conference on Sustainable Cities. - 2016. - Vol. 6.

Makarova I., Pashkevich A., Shubenkova K., Mukhametdinov E. Ways to Increase Population Mobility through the Transition to Sustainable Transport // Procedia Engineering. - 2017b. - Vol. 187. P. 756-762.

Makarova I., Shubenkova K., Mavrin V., Boyko A., Katunin A. Development of sustainable transport in smart cities // In: RTSI 2017 - IEEE 3rd International Forum on Research and Technologies for Society and Industry. - 2017c. - Conf. Proceedings, 8065922.

Makarova I., Shubenkova K., Mavrin V., Buyvol P. Improving safety on the crosswalks with the use of fuzzy logic // Transport Problems. - 2018. - Vol. 13, No. 1. - P. 97-109.

Richardson N., Doubek F., Kuhn K., Stumpf A. Assessing truck drivers' and fleet managers' opinions towards highly automated driving // Advances in Human Aspects of Transportation. - 2016. Vol. 484. - P. 473-484. 
Shubenkova K., Makarova I. Evaluation of the actions aimed at the transition to sustainable public transport system // The Archives of Automotive Engineering. — 2018. - Vol. 81, No. 3. P. 75-90.

Stadkowski A., Pamula W. Intelligent Transportation Systems - Problems and Perspectives // Studies in Systems, Decision and Control. — 2015. - Vol. 32. - 312 p.

Stańczyk U., Zielosko B., Żabiński K. Application of Greedy Heuristics for Feature Characterisation and Selection: A Case Study in Stylometric Domain // Lecture Notes in Computer Science. 2018. - Vol. 11103 LNAI. - P. 350-362.

Strategy of social and economic development of the city of Naberezhnye Chelny until 2021 and for the period up to 2030. Naberezhnye Chelny (2016) [Electronic resource]. - URL: http://nabchelny.ru/page/287 (accessed: 03.09.2020).

Stukalov G. V. Functional Planning Solutions for Urban Residential Areas on Sustainable Development Principles // Prospects of science. - 2013. - No. 3. - P. 38-45.

Sustainable urban development [Electronic resource]. - URL: http://www.leadnet.ru/tet/t9.htm (accessed: 03.09.2020).

Tetior A. Deep ecologization as topical basis of ecological construction // CESB 2007 PRAGUE Int. Conf. - Central Europe Towards Sustainable Building.

Ministry of the Interior of the Russian Federation [Electronic resource]. — URL: http://stat.gibdd.ru/ (accessed: 15.06.2020).

Traffic police [Electronic resource]. — URL: http://stat.gibdd.ru/ (accessed: 03.09.2020).

United Nations Environment Programme [Electronic resource]. — URL: https://www.unenvironment.org/ (accessed: 03.09.2020).

Zhou C., Chinnam R. B., Dalkiran E., Korostelev A. Bayesian approach to hazard rate models for early detection of warranty and reliability problems using upstream supply chain information // International Journal of Production Economics. - 2017. - Vol. 193. - P. 316-331.

Zielosko B., Żabinski K. Optimization of decision rules relative to length based on modified dynamic programming approach // Intelligent Systems Reference Library. — 2018. — Vol. 138. — P. 73-93. 